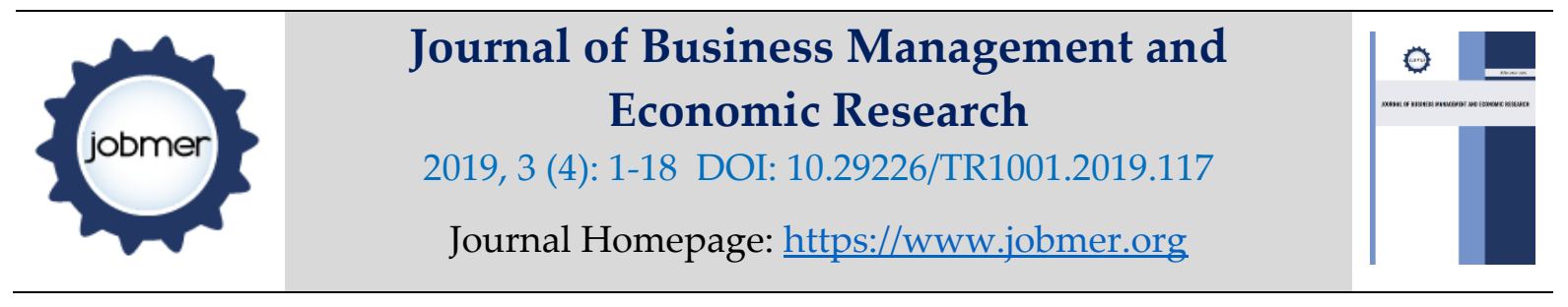

\title{
Applying HACCP in the Tunisian Olive Oil Industry: A Theoretical Background
}

\author{
Abderahman Rejeb \\ Széchenyi István University, Hungary \\ abderrahmen.rejeb@gmail.com \\ John G. Keogh \\ University of Reading, Henley Business School, UK \\ john@shantalla.org
}

\begin{abstract}
Olive oil has proven nutritional value and can command a high market price for farmers and processors. It promises significant income generating potential as well as social empowerment. To meet consumers' expectations for quality, safety and authenticity, olive oil products should be grown, harvested and processed according to internationally recognized food safety management standards. Instead of retrospectively inspecting and testing the end-product, a preventative approach that anticipates potential biological, chemical and physical hazards at all stages of the value chain should be incorporated to preserve the quality and ensure the safety of olive oil and olive fruits. In this research paper, we overlay a HACCP food safety management system on the olive oil value chain in Tunisia. Given the importance of Tunisia in the international market of olive oil, we discuss HACCP in context of the country specificities and we analyze the possibilities and challenges of implementing HACCP in the Tunisian olive oil industry. HACCP promises several advantages including the preservation of product quality and safety for human consumption. Moreover, HACCP can aid Tunisian export sales, improve customers satisfaction and enhance Tunisian branding and marketing. However, this food safety management system requires the commitment of significant resources and the engagement of all stakeholders in the plan.
\end{abstract}

Keywords: Olive Oil Industry, HACCP, Tunisia, Quality, Opportunities, Challenges.

\section{Introduction}

Olive tree cultivation is an ancient practice which dates back to 2500 BC according to Boskou (2006). Presently, olive oil is traded as a very valuable commodity in the global agri-food industry. Scholars have researched its nutritional value and utility to benefit human health and well being (Martín-Peláez et al., 2013) 
Moreover, its high price presents an attractive income generating potential for farmers and processors and enables social empowerment. Consumers around the world are increasingly preferring olive oil or extra virgin olive oil for its nutritional and sensory properties including taste and aroma (Bosque-Sendra et al., 2011). In parallel with the increasing demand for high-quality products and the tendency to seek safe and authentic foods, olive oil producers must adopt internationally recognized food safety management systems to meet customers expectations. Moreover, food safety regulations is a key driver for olive oil producers to apply food safety management programs that encompass the entire olive oil value chain, rather than covering a specific process in the olive oil production. Instead of inspecting and testing the endproduct, an approach that anticipates and prevents any potential hazards or physical damage should be incorporated to preserve the quality of olive oil products from the beginning of the process to the end of the marketing chain, meaning, from the farm to the table (Harris et al., 1995). In this context, Hazard Analysis Critical Control Points (HACCP) is a internationally recognized systematic approach which focuses on risk management and prevention to ensure food safety and conformity with quality standards (Tian, 2017). The application of a HACCP program allows for monitoring and preventative control of potential hazards (i.e., biological, chemical or physical) that could compromise the quality of olive oil and jeopardize consumers' health and safety.

The study of a HACCP management system is important in the Tunisian context because the olive oil industry plays an important role in spurring economic growth but lacks a research focus. Tunisia is one of the world's top olive oil producing countries embraces the growing global demand for olive oil (Karray, 2006). Olive tree cultivation in Tunisia dates back to the 8th century BC and before the founding of Carthage (Larbi \& Chymes, 2010). The Romans furthered the expansion of olive cultivation in the country by increasing irrigation and developing techniques for oil extraction. In modern times, the olive oil sector plays an important role in the social and economic life of Tunisia by providing both employment and export revenue. In volume terms, Tunisia is ranked the world's third largest producer of olive oil with 279,000 tons in 2013 (Zaied \& Zouabi, 2016). The production of olive oil is mainly export-oriented, ranking Tunisia second after the European Union in olive oil exports. The quantity exported represents $70 \%$ of the total production and approximately 16\% of the global exports (Larbi \& Chymes, 2010). Several qualities of olive oil are destined for export and almost exclusively virgin olive oil. The main traditional importers are the European countries which receive olive oil in bulk and at low commodity prices with approximately $60 \%$ of the total exported quantity to Italy, $20 \%$ to Spain and $11.4 \%$ to the USA. 
The economic policies and the structural and institutional reforms undertaken by the agricultural sector in Tunisia have helped to promote the modernization and the adoption of technology in the agricultural growing activities (Larbi \& Chymes, 2010). Besides, several incentives are undertaken to promote the production and marketing of olive oil that is produced in Tunisia with a Tunisian brand and destined for export. Indeed, despite all of these incentives, the olive oil industry exhibits weak efforts for quality preservation and product valorization (conditioning, geographical indication, and appellation of origin etc.) (Karray, 2014). Similarly, the intensification of olive cultivation along with the shift to irrigation directs the attention of industrialists and producers to place more importance on the quantity of ground olives rather than on the quality of the extracted olive oil itself.

Along the entire olive value chain, many factors influence the quality of olive oil. For instance, orchard cultivation practices such as the selection of olive grove variety, pruning, fertilization and plant health treatment are essential for the full development of the agronomic characteristics of the tree that determines the quality of the extracted olive oil (Boskou, 2000). Likewise, the harvesting methods (i.e., traditional or mechanical) and pre-extraction storage are the most critical stages in determining the oil quality (Rabiei, Ghorbani, \& Hajnajari, 2011; Kiritsakis et al., 1998; Vossen, 2009). The downstream supply chain activities involving packaging and retailing including retail shelf storage can results in quality deterioration if not properly managed. Therefore, mitigating contaminations risks and hazards should be a key priority for Tunisian olive oil producers. To achieve this, the present study proposes a theoretical and practical framework for application of a HACCP management system that addresses the potential risks and hazards pertaining to the olive oil value chain. Previous studies on the subject limit the application of HACCP to risks and hazards encountered in the extraction processes (El-Kalyoubi, Abd El-Razik, \& Abou-Zaid, 2013) , with a lack of research in other equally important stages of the olive oil value chain. Thus, this identified gap in the literature is what this work is intended to fill.

In addition, there is a lack of research dealing with the possibilities of a HACCP system specifically for Tunisian olive oil producers. Even though the 'National Program of Promotion of the Quality' enabled support to companies in the implementation of quality management systems (Meybeck \& Redfern, 2014), these initiatives remains underutilized for many reasons. Nevertheless, with the revised government orientation towards protecting consumers and increasing exports of Tunisian branded olive oil, the adoption of the HACCP management system will provide positive benefits to Tunisia. For example, compliance to HACCP not only provides an internationally recognized global certification, it also helps to assure product quality and safety as well as competitive access to international markets. 
Hence, the remainder of the paper is divided as follows. Section 2 introduces the olive oil sector in Tunisia in detail. Section 3 presents the HACCP system along with the different hazards and risks that might be encountered throughout the entire olive oil value chain. Section 4 discusses the possibilities and challenges of implementing such a system for Tunisian olive oil producers. The last section covers a brief conclusion for the paper.

\section{The Olive Oil Sector in Tunisia}

The olive oil sector is well established in Tunisia. It covers 1.7 million hectares or $30 \%$ of the total arable land and about $19 \%$ of the world olive orchards and $8.44 \%$ of the world olive oil in 2017/2018 crop year (Radinovsky, 2019). Several varieties of olives are spreading throughout the country and their geographical breakdown indicates that the crop extends from the northern region to the southern region where twothirds of the total olive growing area is in arid or semi-arid conditions (Abdelhamid et al., 2013). The olive production in Tunisia is based on two main cultivars: "Chetoui" in the north and "Chemlali" in the center and south of the country. Furthermore, olive oil processing is composed of three extraction systems that coexist: the continuous system, which is the most widespread, the super-press and the traditional method (i.e., classic). Equally, the extraction industry involves more than 1,700 mills in which traditional triturating units are more numerous than continuous (Issaoui et al., 2015). They are broken down as follows: 628 classic units, 388 Super-Press and 718 continuous chains (Angulo et al., 2011). Some olive extraction units combine different types of processing units and are referred to as mixed units. Additionally, Tunisia has a spatial concentration of 40 industrial units for olive oil packaging, 15 refineries, 14 units pomace oil extraction and more than 100 exporters (Abdelhamid et al., 2013). Combined, these resources offer great potential for capacity building to reinforce and grow the sector. With this as context, a strategic option for the Tunisian government is to increase the number of continuous olive mill units.

The labor force is estimated to exceed one million workers comprising mainly of seasonal workers directly recruited during the harvesting process and 269,000 regular farmers dedicated to the growing of olives (Angulo et al., 2011). The mechanical harvesting is in its infancy stage and only $9.1 \%$ of farmers use canopy or self-propelled vibratory shakers (Issaoui et al., 2015). Olives are harvested at the point of ripening; meaning that they reach their maturity state or the green-yellow or black-purple stage (Boskou, 2000) and the oil accumulation in the olive fruit (or drupe) is maximized and suitable for harvest (García \& Yousfi, 
2006). Ninety-eight percent of the olive oil extracted from the olive drupes is supplied to countries in bulk at a reduced or zero customs duties. The large European bottling and refining companies blend the Tunisian virgin olive oil with oils from other regions, then bottle and market it using their private brands and labels. Some private Tunisian firms bottle and brand for the export market although the volume is approx. $2 \%$ of the total exports (Mtimet et al., 2013). Unlike the other traditional producing countries, the consumption of olive oil per person in Tunisia is very low (approximately $4 \mathrm{~kg} /$ capita/ year) (Angulo et al., 2011). Tunisian consumers often buy olive oil in bulk directly from the producers. Domestic consumption of bottled olive oil is mainly driven by consumers in cities such as the capital Tunis where consumer trends include one-stop shopping in modern retail (supermarkets).

In order to boost the olive oil industry, Tunisia has undertaken a series of economic and institutional reforms (Larbi \& Chymes, 2010). Measures have been taken by the Tunisian government to ensure stable production and to mitigate harvest quantity fluctuations by encouraging the use of irrigation (intensive or hyper-intensive growing) and increasing the proportion of irrigated olive orchards (2\%) (Angulo et al., 2011). Facing increased international market competition, the government has taken several measures to support and reinforce the industry by promoting the consumption and export of bottled and branded olive oil (versus commodity priced bulk). The encouragement of exports has been the task of various funds created recently such as FOPRODEX, FOPROHOC and FAMEX that made a substantial contribution in enhancing export performance. Regardless of these facts, the many mentoring programs (e.g., good cultural practices and guidance), training, promotion, and institutional support have not significantly altered the existing production practices and have not contributed to the development of quality management systems (Karray, 2012). Moreover, a study conducted by Kashiwagi et al. (2016) revealed that among Tunisian olive oil producers, only 28 firms in the survey sample $(n=113)$ introduced quality control measures $(24.8 \%)$. However, this situation is no longer tolerable especially after the creation of the Euro-Mediterranean Free Trade Area and the removal of trade barriers. Quality management systems need to become more stringent as olive oil producers are transacting in a highly competitive environment. Furthermore, exports going to countries such as Japan, USA and Canada have to achieve high quality and regulatory compliance. These pressures combine with end customers' expectations and become strong drivers for olive oil producers and processors to participate in quality programs (i.e., HACCP) (Trautman, Goddard, \& Nilsson, 2008). According to Euromonitor (2017), companies are focusing on innovations including glass and ceramic bottles and labels that stress health benefits as well as quality and provenance. They note that some brands are selling for as much as USD 78 for $500 \mathrm{ml}$ making them a luxury good. However, it is well known that 
'fake' olive oil is one of the top 10 economically motivated adulterations. For example, blended olive oils are passed off as premium priced extra virgin olive oil and the country of origin (provenance) is often misstated (Squires, 2015).

\section{Theoretical Framework of HACCP System in the Olive Oil Industry}

Originally, HACCP was developed as a system for monitoring and control of food safety. It aims to provide deeper insights into operations which are subject to hazards and risks and to determine the preventive measures for anticipating them. In the context of olive oil industry, HACCP serves the purpose of specifying the rules to be followed by olive oil mills and packaging units regarding hygiene practices, environmental protection, hazard identification and evaluation of critical control points (Goula, Kiritsakis, \& Kiritsakis, 2017). These latter points represent the key steps in the process that must be controlled to ensure the quality and safety preservation of the olive oil. Moreover, the critical limits are set to ensure that the acceptable level of each hazard at each critical control point is not exceeded (Walaa et al., 2013). The quality of the olive oil produced is determined by a set of significant factors that encapsulate the cultivation practices, harvesting methods, transportation, post-harvest storage, extraction process, storage of olive oil, and retail \& distribution.

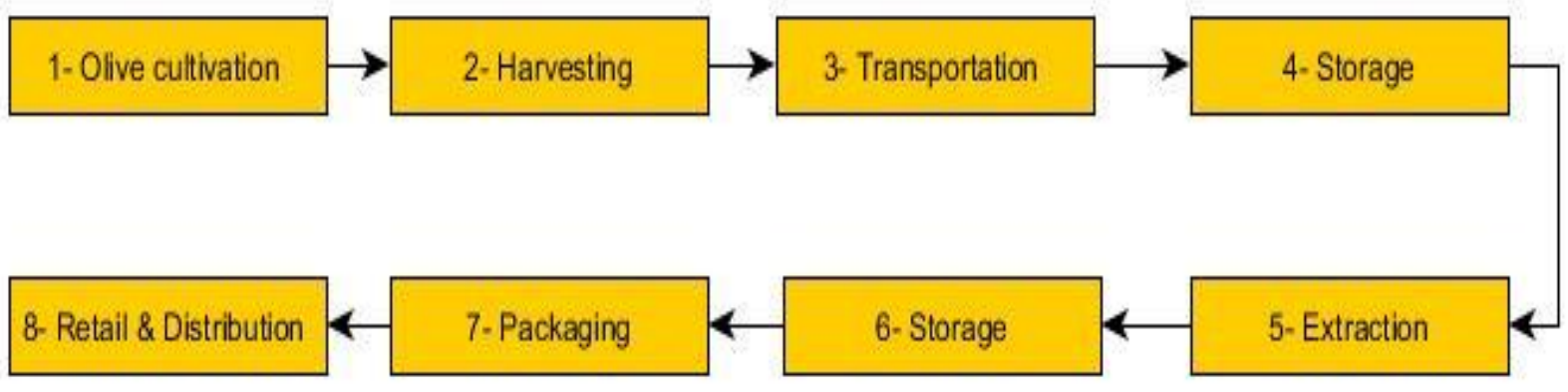

Figure 1. The typical process steps of olive oil (Authors)

Figure 1 shows the process steps of olive oil production. The critical control points will be defined and determined accordingly. All the points in this study pertain to the whole olive oil value chain and if they are identified, controlled and monitored, olive oil producers will prevent and eliminate possibilities of degrading the quality of the product.

- CCP1_Risks associated with olive cultivation 
Olive cultivation involves all the activities necessary for the development of olives tree and fruit. The selection of varieties, the irrigation system and the sanitary treatments applied to the trees (e.g., pesticides, pruning, etc.) affect the olives quality and ripening rate (Rejeb, 2018; Apostolos Kiritsakis \& Sakellaropoulos, 2017). Potential hazards in this stage include the excessive irrigation, the overuse of pesticides and the inadequacy of their timing, the infestation of pests, and the attack of weeds etc.

\section{- $\quad$ CCP2_Risks associated with harvesting}

Harvesting is the most critical step in the olive oil value chain because it accounts for a significant portion of production costs and influences the quality of produced olive oil (Abenavoli \& Marcianò, 2013). Risks to quality are split between physical and chemical hazards. The former are directly associated with the olives fruits. They encompass the leaves and small branches attached to the collected olive fruits as well as the inappropriate scheduling and delay of harvesting. Moreover, the over-ripeness of fruits in the difficult to reach tree trunk area poses a risk to the quality (Boskou, 2006). The chemical hazards are increasing due to pesticides residues and the effects of improper harvesting methods. For instance, any breakage and damage of fruit causes the increase in free fatty acids and peroxides levels (Saglam, Tuna, \& Gecgel, 2014), leading thus to a degradation in the quality of extracted olive oil in a later processing stage.

\section{- CCP3_Risks associated with transportation}

Before reaching the olive mills, the fruits need to be carefully packaged and transported in order to preserve the quality of the agricultural crop. Risks in this phase include the improper handling and packaging during the transportation activities. For example the olive fruits or 'drupes' can be squashed in plastic bags or sacks. They are susceptible to damage during loading and unloading at farms and processing plants (Goula et al., 2017), and risk the development of undesirable enzymatic reactions (e.g., oxidation). To put this in context, a common but inappropriate practice endorsed by many Tunisian farmers is the use of jute or plastic sacks for transportation. This habit increases the acidity of olive oil and negatively affects its quality (Kashiwagi et al., 2016).

\section{- CCP4_Risks associated with storage (olives)}

One of the most important factors for influencing olive oil quality is the post-harvest storage of olive drupes. Previous studies on this topic have shown many risks that could be encountered during the storage of drupes prior to milling (Brenes et al., 1993; García et al., 1996; Agar et al., 1998). The most common risk in storage is the extended holding time of drupes before oil extraction. The reason for this is the desynchronization in the timing between olive processing and harvesting. This is a common coordination 
issue in Tunisia where the production of olives is very high and concentrated in a short time span. As a result, most olive mills are capacity constrained to deal with the high quantities of olives. Moreover, when the olives are stored for an extended period in plastic sacks or in deep and large mounds, they are subject to physical, chemical and biological hazards that affect the nutritional and sensory profile of the oil (Vichi et al., 2009). For example, the flavor of extracted oil could be classified as fusty, winey or musty due to, respectively, the degradative phenomena (i.e., loss of texture and damage of skin), the fermentation, and the considerable fungal invasion (or pathogens) during the fruit storage (Angerosa, 2002) .

\section{- CCP5_Risks associated with extraction}

Arguably, the quality of olive oil is directly dependent on the quality of the fruit from which it is extracted (García \& Yousfi, 2006). Besides, the handling practices and operations implemented during the extraction process play a significant role in determining the quality of olive oil.

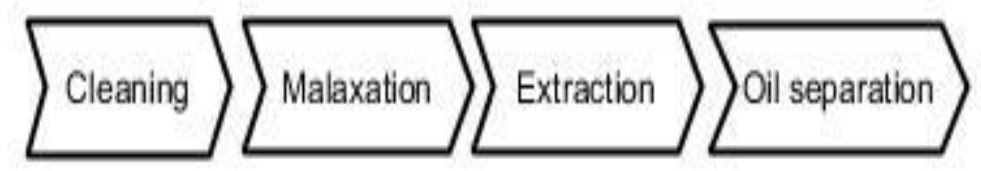

Figure 2. The extraction process (Authors)

As shown in figure 2, the extraction process encompasses the cleaning, malaxation or kneading, extraction, and separation of oil. Under certain circumstances, olives are harvested during harsh weather elements such as heavy rains, frosts and sometimes snow. Thus, olives might be squashed with contaminants such as mud, dust, dirt and moisture. Not only that, the harvested olives contain leaves, twigs, and sprigs that dramatically affect the fruit oil content (Vossen, 2009). For that reason, cleaning the olive drupes is necessary before malaxation because the presence of leaves and other materials intensify the green-leaf organoleptic property of oil causing a bitter and pungent taste (Giovacchino, 2013). However, the cleaning task (including leaves removal and washing) is subject to many potential risks and hazards. For instance, although washing drupes eliminates the presence of foreign materials, there is a risk of removing some pulp tissue and consequently result in oil losses (Giovacchino, 1996). Moreover, the excessive reuse of washing water for removing impurities may lead to bacterial contamination and induce adverse effects on the quality of olive oil. Similarly, contaminations may result from the use of any chemicals in the process (e.g., disinfectants, detergents etc.). 
The malaxation or kneading introduces several contamination risks to the oil through equipment and humans (Tzia, Oreopoulou, \& Kallisperi, 1997). These include the possible microbial contents, enzymatic pathways, and the formation of emulsions. Further, the degree of crushing, the malaxation temperature and time affect the concentration of the volatile compounds and the sensory characteristics of the produced oil (Angerosa, 2002). As a case in point, the intense crushing of olives by the metallic hammer crusher or mill stones for a long time and in high temperature results in off-odor formation. Potential risks involve contaminations caused by the state of the equipment used in the process (malaxer, hammer or disc crusher, rollers, machine lubricant oils or greases etc.) and the poor hygiene practices of workers. At the oil extraction stage, any inappropriate practices increases the formation of fatty acids, enzymatic reactions, and other microorganisms. Besides, the presence of impurities in water and unsanitary pressing mats will degrade the quality of olive oil. The final liquid containing the oil and vegetation water will be filtrated and separated by a standard process of decantation or centrifugation. The risks here might be associated with the inadequate pressure and decanter parameters, the water chemicals, and the emulsions etc.

\section{CCP6_Risks associated with storage (olive oil)}

Subsequent to the final extraction of olive oil and before reaching the packaging units, olive oil undergoes an intermediate storage step. The storage conditions affect the quality of olive oil and multiple risks are present. For example, the physical risks include the usage of unsuitable or unsanitary drums or containers that are rusted or permeable to oil, light and air. The improper sealing of containers increases the risk of foreign materials infiltration such as insects and dust. The stored oil might be subject to oxidation or contamination from the tank (e.g., bacteria, sediments, moulds and yeasts, etc.), the exposition to light, the high storage temperature.

\section{CCP7_Risks associated with packaging}

Packaging is a very critical step in the olive oil value chain. Aside from influencing the marketability of the products, the packaging serves to protect the olive oil until they reach consumers. Besides, the use of proper packaging helps not only to ensure the adequate shelf life for distribution and retail but also to keep contaminants at bay. The physical characteristics of the packaging material may have a considerable effect on the final quality of the oil, depending on the degree of the deteriorative interactions (Kiritsakis \& Dugan, 1985). Previous studies on the impact of packaging on the olive oil quality show that olive oil stability is retained only if the olive oil products are protected for certain hazards like oxygen and light (Kanavouras, Hernandez-Munoz, \& Coutelieris, 2004; Kiritsakis et al., 1998). Similarly, the packaging materials might 
transfer chemical risks into the oil. For instance, the use of plastic bottles and containers causes the increase in peroxide values and facilitates the oxidation of olive oil due to their permeability (Issaoui et al., 2010) (Kiritsakis \& Dugan, 1985). There is also a risk of photo-oxidation and decrease of shelf life in case of using transparent materials for bottling olive oil ( Gutierrez, 1975; Mastrobattista, 1990; Akoh, 2017).

\section{CCP8_ Risks associated with retail $\mathcal{E}$ distribution}

Ineffective food safety and quality control in the distribution and retail stage can result in spoilage. Moreover, incorrect storage and handling along with various forms of illicit trade and food fraud may cause substantial financial losses including reputational damage and severe legal obligations (i.e., penalties, fines, lawsuits etc.) (Moyer, DeVries, \& Spink, 2017). At retail outlets, the on shelf-storage conditions have a significant impact on the quality of olive oil. That is, the length of holding time in the store and the environmental factors (e.g., temperature, humidity, light etc.) might change the quality characteristics of the olive oil products. For example, the high intensity of light in the store can accelerate the oxidation of oil (Dabbou, 2011). Similarly, the longer olive oil products remain in retail and unsold impacts on the acidity of the oil and the intensity of rancidity.

Table 1: Generic HACCP Management Applied to the Olive Oil Industry (Authors)

\begin{tabular}{|l|l|l|}
\hline $\begin{array}{l}\text { Critical } \\
\text { Control } \\
\text { Points } \\
\text { (CCPS) }\end{array}$ & \multicolumn{1}{|c|}{ Monitoring Procedures } & \multicolumn{1}{c|}{ Preventive and Corrective Actions } \\
\hline CCP1 & $\begin{array}{l}\text { Plant control (pruning, irrigation, light interception, } \\
\text { tree spacing etc.) } \\
\text { Pests control } \\
\text { Pesticide and fertilizers monitoring (insecticides, } \\
\text { disease pests) } \\
\text { Fertility management }\end{array}$ & $\begin{array}{l}\text { Organic cultivation } \\
\text { Better cultivation management } \\
\text { Avoid intensive irrigation, soil conditioners } \\
\text { Maintenance and sanitation programs } \\
\text { Optimal usage of pesticides, insecticides, and } \\
\text { herbicides } \\
\text { Appoint agronomist or specialists for regular } \\
\text { monitoring before harvesting } \\
\text { Document actions taken }\end{array}$ \\
\hline CCP2 & $\begin{array}{l}\text { Heavy metals control } \\
\text { Scheduling harvest time (appropriate stage of fruit } \\
\text { maturity) } \\
\text { Control olives ripeness } \\
\text { Visual inspection of the collected olives } \\
\text { Extension and moving of nets }\end{array}$ & $\begin{array}{l}\text { Use of appropriate equipment for high fruit removal } \\
\text { efficiency while reducing damages } \\
\text { Better training of the usage of mechanical aids and } \\
\text { machines used in harvesting (e.g., shakers) } \\
\text { Avoid the use of "vareo" (shaking the tree with rods) } \\
\text { Separate olives gathered from both the ground and the } \\
\text { tree } \\
\text { Reduce as much as possible twigs and leaves } \\
\text { Document actions taken }\end{array}$ \\
\hline
\end{tabular}




\begin{tabular}{|c|c|c|}
\hline CCP3 & $\begin{array}{l}\text { Transport monitoring (time, conditions) } \\
\text { Careful loading of olives } \\
\text { Visual monitoring }\end{array}$ & $\begin{array}{l}\text { Good transportation handling, cleaning of trucks } \\
\text { Avoid the use of rusted tractor pan or containers } \\
\text { Avoid the use of plastics and jute sacks } \\
\text { Use of open-mesh transportation and perforated boxes } \\
\text { Document actions taken }\end{array}$ \\
\hline ССР 4 & $\begin{array}{l}\text { Monitor the storage conditions (temperature and } \\
\text { time) } \\
\text { Rejection of fruit batches that do not meet the } \\
\text { requirement of the mills } \\
\text { Visual inspection }\end{array}$ & $\begin{array}{l}\text { Ensure better storage timing and temperature }\left(5^{\circ} \mathrm{C} \text { in }\right. \\
\text { air for at least } 30 \text { days could be recommended } \\
\text { according to (Kiritsakis et al., 1998)) } \\
\text { Regulate temperature, humidity } \\
\text { Ensure the cleanness of storage to prevent mould } \\
\text { formation } \\
\text { Selection of appropriate unit loads that contain the } \\
\text { olives } \\
\text { Document actions taken }\end{array}$ \\
\hline ССР5 & $\begin{array}{l}\text { - Cleaning } \\
\text { Hygiene monitoring } \\
\text { Visual inspection of washing water (color, odor etc.) } \\
\text { Monitoring of the equipment } \\
\text { Cleaning of chemical residues } \\
\text { Optical inspection of the defoliator } \\
\text { - Malaxation } \\
\text { Monitoring the malaxation temperature, processing } \\
\text { time, and velocity. } \\
\quad \text { - Extraction and separation of oil } \\
\text { Monitor the processing time, water quality, } \\
\text { temperature etc. } \\
\text { Regulate the pressure or decanter parameter } \\
\text { Control the hygiene practices (e.g., decanter and } \\
\text { pressing mats etc.) } \\
\text { Periodic optical inspection of the equipment }\end{array}$ & $\begin{array}{l}\text { Frequent renewal of the washing water } \\
\text { Preventive programs of maintenance and cleaning } \\
\text { Disinfection of equipment (e.g., defoliators) } \\
\text { Cleaning efficiency } \\
\text { Training personnel for good hygiene practices } \\
\text { Preventive and corrective programs of maintenance, } \\
\text { cleaning and disinfection of equipment } \\
\text { Apply the recommended average malaxation time (60 } \\
\text { min, } 35^{\circ} \mathrm{C} \text { ) } \\
\text { Reduce temperature in case of over-heating } \\
\text { Plant predictive maintenance } \\
\text { Improve the handling practices } \\
\text { Operators training programs } \\
\text { Remove any sediments } \\
\text { Document actions taken }\end{array}$ \\
\hline ССР6 & $\begin{array}{l}\text { Monitor the storage temperature } \\
\text { Visual inspection of the tank deposits } \\
\text { Control storage area (free from moisture, } \\
\text { unpleasant aroma, light) } \\
\text { Control oil from any traces of water, impurities, and } \\
\text { solid residues }\end{array}$ & $\begin{array}{l}\text { Absence of air } \\
\text { Use of storage containers made from inert materials } \\
\text { (stainless steel or inox) } \\
\text { Remove any sediments from the tanks and containers } \\
\text { Ensure that tanks are clean and dry } \\
\text { Protect oil form intensive lighting } \\
\text { Completely fill the tanker and the containers } \\
\text { Loading tanks from the bottom to minimize the contact } \\
\text { with the air } \\
\text { Document actions taken }\end{array}$ \\
\hline
\end{tabular}




\begin{tabular}{|l|l|l|}
\hline CCP7 & $\begin{array}{l}\text { Inspection of the packaging units } \\
\text { Monitoring the hygiene conditions in the packaging } \\
\text { units } \\
\text { Monitoring of the equipment used in packaging } \\
\text { (e.g., pumps, filters, volumetric fillers etc.) } \\
\text { Control workforce hygiene }\end{array}$ & $\begin{array}{l}\text { Use of dark glass in bottling, if transparent glass is used } \\
\text { then bottles and small containers should be protected } \\
\text { from light in the unit loads } \\
\text { Integrity of labelling instructions } \\
\text { Interacting with reliable suppliers of packaging } \\
\text { materials } \\
\text { Training programs for the workforce (personal } \\
\text { hygiene, sanitary dressing and appropriate uniforms, } \\
\text { proper product handling etc.) } \\
\text { Document actions taken }\end{array}$ \\
\hline CCP8 & $\begin{array}{l}\text { Site documentation } \\
\text { Monitor time, on-shelf storage conditions } \\
\text { (temperature, humidity, lights) }\end{array}$ & $\begin{array}{l}\text { Regulate storage conditions in the store, humidity, } \\
\text { light, temperature, keep olive oil products in dry places } \\
\text { Palletization of unit loads for better transportation and } \\
\text { handling } \\
\text { Review preventive procedures } \\
\text { Document actions taken }\end{array}$ \\
\hline
\end{tabular}

\section{Possibilities and Challenges of HACCP implementation in Olive Oil Industry in Tunisia}

\subsection{Possibilities of HACCP}

The adoption of a HACCP system by the olive oil producers in Tunisia is beneficial in various aspects. The system aims to identify, control and contain risks and hazards that might be encountered on the olive oil value chain. As we have previously stated, the system is applicable to the whole process of olive oil processing from farm to table. This would, in turn, confirm the compliance of the produced olive oil to the various food safety regulations and the very thorough due diligence practiced throughout all the value chain phases. Besides, the broad implementation of HACCP has the potential to enhance the industry reputation and increase exports from Tunisia. This is because the system is highly credible and recognized in global trade agreements through the World Trade Organization (Wallace, Sperber, \& Mortimore, 2018). The weak competitive position of Tunisia compared to other dominant countries on the international market for olive oil (e.g., Italy, Spain, Greece) might be strengthened by the development and the sound application of HACCP system (Karray, 2006). Similarly, the Tunisian olive oil companies will have the ability to penetrate new markets and generate significant revenue streams while meeting the stringent requirements for high quality olive oil products.

Besides facilitating a safer value chain, the HACCP system shifts the focus from retrospectively controlling the quality to proactively curbing all probable risks and hazards in the olive oil value chain. In doing so, the Tunisian olive oil producers will reduce wastage and defects (e.g., sensory, aroma, color etc.). Moreover, 
they can reduce the costs associated with loss of sales and ineffective end-product testing. Tighter controls will be exercised over the most critical and sensitive stages in the value chain. Thus, this allows the operators to engage in total quality programs and efficient traceability systems. A HACCP program in Tunisia builds capacity on food safety with farmers and processors and enables the sale of higher quality and traceability products with greater profit margins. HACCP facilitates regulatory requirements and the needs of certification bodies and leads to a more effective controls and supervision of the sector.

\subsection{Challenges of HACCP Implementation in Tunisia}

Although the implementation of HACCP promises many advantages to the Tunisian olive oil producers, there are still many barriers inhibiting its adoption. One of the most problematic issues is the lack of appropriate training in HACCP methodology (Taylor, 2001). In fact, the system induces many changes in the ways to manage the olive oil value chain to ensure quality and safety of the end product. The businesses involved in the sector are required to engage in capacity building including classroom training, frequent meetings and awareness programs regarding the best working, hygienic, and safety practices. In addition, firms need to engage with specialized teams and independent experts to increase the level of knowledge and understanding of microbiological and chemical issues. For the sake of doing so, the commitment of resources (e.g., time, money, and people etc.) is necessary. Furthermore, the move in this direction implies the incurrence of costs that are often prohibitive for some entities in the industry, particularly small and medium enterprises. Small and medium businesses generally have limited funds, older equipment and reduced bargaining power. Therefore, the costs of implementing a HACCP plan might outweigh the benefits of embedding it into the sector initially.

Another prevalent problem hampering the implementation of HACCP is the willingness and readiness of olive oil supply chain partners to cater to the needs of this quality management system. Similarly, the perception of the industry actors regarding the potential risks might be divergent and often conflicting. For instance, olive growers will only focus attention on the damage and contamination on the external surface of the olive fruits, while the olive mill plants will be more concerned with the control of the microbiological and chemical risks. This antagonism of interests and divergence in risk perception ends in confusion, information asymmetry and loss of control. The same applies to low-skilled workers who may have low

motivation to learn, may resist change and not willing to engage in learning and mastering the necessary skills for absorbing the prerequisites of the HACCP plan. Lastly, any significant industry upgrading might 
lead to the failure of the existing HACCP system since the processes are continuously changing due to many dynamics (e.g., technologies, national and international regulations, trade standards, foodborne diseases etc.)

\section{Conclusion}

In this paper, we have developed a HACCP plan that covers the olive oil value chain, from olives cultivation to the storage of the final products in the retail store. HACCP procedures and steps are developed to address all the potential risks and hazards that might be encountered in the supply chain. Unlike previous studies on the subject that are exclusively based on the development of a HACCP plan at the olives mill plants level, we emphasize the exploration of the hazards and risks preceding and succeeding the operations of extraction units. In doing so, the HACCP plan will be fully-fledged and help to preserve the quality of olive oil products.

The implementation of the HACCP plan does not only guarantee the high quality of olive oil products but it could contribute to the country economy. Being a valuable commodity, Tunisia could derive many benefits from the sound and correct application of HACCP in the olive oil industry. This falls within the remit of olive oil supply chain stakeholders (i.e., farmers, olive oil processors, packaging units, distributors, exporters, certification bodies etc.).

By establishing these preventive procedures, the enhanced traceability of olive oil can be linked to data from analytical laboratories or government agencies who verify the safety and authenticity of the olive oil. Moreover, demonstating batch or lot traceability facilitates a rapid recall of the product should a contamination occur (Kumar, 2007). Furthermore, the adoption of HACCP in the olive oil industry promises many advantages to the operators, namely, marketing and branding benefits.

Despite the possibilities of a HACCP system in the olive oil industry in Tunisia, its implementation might be challenging due to the limited technical expertise, resources, and the organizational reluctance. The difference in perceiving hazards and risks pertaining to the olive oil value chain might lead to control dilution. The need to keep the HACCP system updated with the industry upgrade, the progress of actions, and the new dynamics is a challenging task to undertake. It should be also noted that according to scholars, current food safety management control systems (such as HACCP) are not specifically designed for fraud control or mitigation due the intentional nature of the fraud and subsequent vulnerability to deception 
(Levine, 2014; van Ruth, Huisman, \& Luning, 2017). Rather, an approach that differs from the common safety ploys is imperative to ensure both food safety and fraud prevention (Spink et al., 2017).

The present study lays the groundwork for further emperical research related to the factors of implementing the HACCP quality management system in the olive oil industry and the barriers that inhibit its effective use. Besides, the cost-benefit analysis of HACCP among Tunisian olive oil businesses leaves a significant potential for future investigation.

\section{Acknowledgement}

The publication of this work was supported by: EFOP-3.6.1-16-2016-00017.

\section{References}

Abdelhamid, S., Gouta, H., Gharsallaoui, M., Ghrab, M., Kwon, T., Yoon, I., \& Byun, M. O. (2013). A Review on Current Status of Olive and Olive Oil Production in Tunisia, 25(4), 351-357.

Abenavoli, L. M., \& Marcianò, C. (2013). Technical and economic analysis of alternative pruning systems in high dimensions olive trees in Calabria. Agronomy Research, 11(1).

Agar, I. T., Hess-Pierce, B., Sourour, M. M., \& Kader, A. A. (1998). Quality of Fruit and Oil of Black-Ripe Olives Is Influenced by Cultivar and Storage Period. Journal of Agricultural and Food Chemistry, 46(9), 3415-3421. https://doi.org/10.1021/jf9803684

Akoh, C. (2017). Food lipids: chemistry, nutrition, and biotechnology. Retrieved from https://www.taylorfrancis.com/books/9781498744874

Angerosa, F. (2002). Influence of volatile compounds on virgin olive oil quality evaluated by analytical approaches and sensor panels. European Journal of Lipid Science and Technology. https://doi.org/10.1002/1438-9312(200210)104:9/10<639::AID-EJLT639>3.0.CO;2-U

Angulo, A. M., Mtimet, N., Dhehibi, B., Atwi, M., Youssef, O. Ben, Gil, J. M., \& Sai, M. B. (2011). A revisited gravity equation in trade flow analysis: an application to the case of Tunisian olive oil exports. Investigaciones Regionales, 21(december), 225-239. Retrieved from http://dialnet.unirioja.es/descarga/articulo/4226669.pdf\%5Cnhttp://dialnet.unirioja.es/servlet/articul o? codigo $=4226669$

Boskou, D. (2000). Olive oil (Vol. 87). https://doi.org/10.1079/9781845934583.0279

Boskou, D. (2006). Characteristics of the olive tree and olive fruit. In Olive Oil (Second Edition) (pp. 13-19). Elsevier.

Bosque-Sendra, J. M., De La Mata-Espinosa, P., Cuadros-Rodríguez, L., González-Casado, A., RodríguezGarcía, F. P., \& García-Toledo, H. (2011). Stability for olive oil control materials. Food Chemistry, 125(4), 1418-1422.

Brenes, M., Garcia, P., Duran, M. C., \& Garrido, A. (1993). Concentration of Phenolic Compounds Change 
in Storage Brines of Ripe Olives. Journal of Food Science, 58(2), 347-350. https://doi.org/10.1111/j.13652621.1993.tb04272.x

Di Giovacchino, L. (1996). Olive harvesting and olive oil extraction. Olive Oil, 12-51.

Di Giovacchino, L. (2013). Technological Aspects. In Handbook of Olive Oil (pp. 57-96). Boston, MA: Springer US. https://doi.org/10.1007/978-1-4614-7777-8_3

Euromonitor, I. (2017). Olive Oil Spotlight: A Legally Healthy Fat Key Offers Great Business Opportunity.

Feng Tian. (2017). A supply chain traceability system for food safety based on HACCP, blockchain \&amp; Internet of things. 2017 International Conference on Service Systems and Service Management, 1-6. https://doi.org/10.1109/ICSSSM.2017.7996119

García, J. M., Seller, S., \& Pérez-Camino, M. C. (1996). Influence of Fruit Ripening on Olive Oil Quality. Journal of Agricultural and Food Chemistry, 44(11), 3516-3520. https://doi.org/10.1021/jf950585u

García, J. M., \& Yousfi, K. (2006). The postharvest of mill olives. Grasas Y Aceites, 57(1), 16-24. https://doi.org/10.3989/gya.2006.v57.i1.18

Goula, A., Kiritsakis, K., \& Kiritsakis, A. (2017). 8 Application of HACCP and traceability in olive oil mills and packaging units and their effect on quality and functionality. In Olives and Olive Oil as Functional Foods: Bioactivity, Chemistry and Processing (p. 147). Retrieved from https://books.google.fr/books?hl=en\&lr=\&id=FtkoDwAAQBAJ\&oi=fnd\&pg=PA147\&dq=Application +of+HACCP+and+traceability+in+olive+oil+mills+and+packaging+units+and+their+effect+on+qualit $\mathrm{y}+$ and+functionality\&ots=II2OV4U7ui\&sig=0qpco7_9V2tbl4c4qeWPhrcMpEE

Gutierrez, G. Q. (1975). Bottling and canning. Olive Oil Technology, 6.

Harris, K. B., Cross, H. R., Acuff, G. R., \& Webb, N. B. (1995). Risk analysis, HACCP and microbial criteria in meat and poultry systems. In HACCP in Meat, Poultry, and Fish Processing (pp. 134-155). Springer.

Issaoui, M., Flamini, G., Brahmi, F., Dabbou, S., Hassine, K. Ben, Taamali, A., ... Hammami, M. (2010). Effect of the growing area conditions on differentiation between Chemlali and Chétoui olive oils. Food Chemistry, 119(1), 220-225. https://doi.org/10.1016/j.foodchem.2009.06.012

Issaoui, M., Gharbi, I., Flamini, G., Cioni, P. L., Bendini, A., Gallina Toschi, T., \& Hammami, M. (2015). Aroma compounds and sensory characteristics as biomarkers of quality of differently processed Tunisian virgin olive oils. International Journal of Food Science and Technology, 50(8), 1764-1770. https://doi.org/10.1111/ijfs.12830

Kanavouras, A., Hernandez-Munoz, P., \& Coutelieris, F. A. (2004). Shelf life predictions for packaged olive oil using flavor compounds as markers. European Food Research and Technology, 219(2). https://doi.org/10.1007/s00217-004-0933-2

Karray, B. (2006). Olive Oil World Market Dynamics and Policy Reforms: Implication for Tunisia. 98th Seminar of the EAAE, Chania, July.

Karray, B. (2012). Enjeux de la filière oléicole en Tunisie et axes de développement dans le nouveau contexte politique. Les Notes d'analyse Du CIHEAM, 66.

Karray, B. (2014). O LIVE OIL au marché européen : une étude Delphi, 21(5).

Kashiwagi, K., Mtimet, N., Zaibet, L., \& Nagaki, M. (2016). Technical efficiency of olive oil firms under the industrial upgrading programme in Tunisia. New Medit, 15(4), 10-20. https://doi.org/http://newmedit.iamb.it/share/img_new_medit_articoli/1079_10kashiwagi.pdf 
Kiritsakis, A. (Paul) K., Lenart, E. B., Willet, W. C., \& Hernandez, R. J. (1998). Olive oil: from the tree to the table. Food \& Nutrition Press.

Kiritsakis, A., \& Dugan, L. R. (1985). Studies in photooxidation of olive oil. Journal of the American Oil Chemists' Society, 62(5), 892-896. https://doi.org/10.1007/BF02541753

Kiritsakis, A., Nanos, G. D., Polymenopoulos, Z., Thomai, T., \& Sfakiotakis, E. M. (1998). Effect of fruit storage conditions on olive oil quality. JAOCS, Journal of the American Oil Chemists' Society. https://doi.org/10.1007/s11746-998-0212-7

Kiritsakis, A., \& Sakellaropoulos, N. (2017). 7 Olive fruit harvest and processing and their effects on oil functional compounds. In Olives and Olive Oil as Functional Foods: Bioactivity, Chemistry and Processing (p. 127). Retrieved from https://books.google.fr/books?hl=en\&lr=\&id=iBsmDwAAQBAJ\&oi=fnd\&pg=PA127\&dq=\%22Moreo ver,+cultivation+practices+influence+the+olive+characteristics+and+ripening+rate.+Indicatively $\% 22$ \&ots=SG0b58NrsN\&sig=LP_skxW1ehY5DPFz4tpwT0nKhnI

Kumar, S. (2007). Connective technologies in the supply chain. Auerbach Publications.

Larbi, W., \& Chymes, A. (2010). The impact of the government policies and incentives to promote the export of agricultural products in Tunisia: The case of olive oil. Food Economics - Acta Agriculturae Scandinavica, Section C, 7(2-4), 107-118. https://doi.org/10.1080/16507541.2010.531952

Levine, T. R. (2014). Truth-Default Theory (TDT): A Theory of Human Deception and Deception Detection. Journal of Language and Social Psychology. https://doi.org/10.1177/0261927X14535916

Martín-Peláez, S., Covas, M. I., Fitó, M., Kušar, A., \& Pravst, I. (2013). Health effects of olive oil polyphenols: recent advances and possibilities for the use of health claims. Molecular Nutrition $\mathcal{E}$ Food Research, 57(5), 760-771.

Mastrobattista, G. (1990). Effect of light on extra virgin olive oils in defferent types of glass bottles. Italian Journal of Food Science, 3, 191-195. Retrieved from http://agris.fao.org/agrissearch/search.do?recordID=US201302665766

Meybeck, A., \& Redfern, S. (2014). Voluntary standards for sustainable food systems: challenges and opportunities. In A Workshop of the FAO/UNEP programme on sustainable food systems.

Moyer, D. C., DeVries, J. W., \& Spink, J. (2017). The economics of a food fraud incident-Case studies and examples including Melamine in Wheat Gluten. Food Control, 71, 358-364.

Mtimet, N., Zaibet, L., Zairi, C., \& Hzami, H. (2013). Marketing olive oil products in the Tunisian local market: The importance of quality attributes and consumers' behavior. Journal of International Food $\mathcal{E}$ Agribusiness Marketing, 25(2), 134-145.

Rabiei, V., Ghorbani, S., \& Hajnajari, H. (2011). Effect of temperature and storage period of olive (Olea europaea cv. Zard) fruit on olive oil quality. Journal of Food, Agriculture E Environment, 9(1), 74-77.

Radinovsky, L. (2019). 2018/19 Worldwide Olive Oil Production Estimates Compared. Retrieved March 3, 2019, from http://www.greekliquidgold.com/index.php/en/news/351-2018-19-worldwide-olive-oilproduction-estimates-compared

Rejeb, A. (2018). The Potentialities of RFID-Based Traceability System in the Olives Post-Harvest Stage. Journal of Business Management and Economic Research, 2(12), 13-25. https://doi.org/10.29226/TR1001.2018.

Saglam, C., Tuna, Y., \& Gecgel, U. (2014). Effects of Olive Harvesting Methods on Oil Quality. APCBEE 
Procedia. https://doi.org/10.1016/j.apcbee.2014.03.050

Samia Dabbou. (2011). Impact of packaging material and storage time on olive oil quality. AFRICAN JOURNAL OF BIOTECHNOLOGY, 10(74). https://doi.org/10.5897/AJB11.880

Spink, J., Ortega, D. L., Chen, C., \& Wu, F. (2017). Food fraud prevention shifts the food risk focus to vulnerability. Trends in Food Science and Technology. https://doi.org/10.1016/j.tifs.2017.02.012

Squires, N. (2015). Italian olive oil scandal: seven top brands "sold fake extra-virgin." The Telegraph. Retrieved from http://www.telegraph.co.uk/news/worldnews/europe/italy/11988947/Italiancompanies-investigated-for-passing-off-ordinary-olive-oil-as-extra-virgin.html

Taylor, E. (2001). HACCP in small companies: benefit or burden? Food Control, 12(4), 217-222.

Trautman, D., Goddard, E., \& Nilsson, T. (2008). Traceability - a Literature Review. Rural Economy (Vol. 8-2). https://doi.org/doi:10.7939/R3T43J47M

Tzia, C., Oreopoulou, V., \& Kallisperi, M. (1997). Quality Assurance and HACCP of Olive Oil. In III International Symposium on Olive Growing (pp. 667-670). Retrieved from https://www.actahort.org/books/474/474_138.htm

Van Ruth, S. M., Huisman, W., \& Luning, P. A. (2017). Food fraud vulnerability and its key factors. Trends in Food Science and Technology. https://doi.org/10.1016/j.tifs.2017.06.017

Vichi, S., Romero, A., Gallardo-Chacón, J., Tous, J., López-Tamames, E., \& Buxaderas, S. (2009). Influence of Olives' Storage Conditions on the Formation of Volatile Phenols and Their Role in Off-Odor Formation in the Oil. Journal of Agricultural and Food Chemistry, 57(4), 1449-1455. https://doi.org/10.1021/jf803242z

Vossen, P. (2009). Olive Oil Processing Technology Influences on Quality. Retrieved from http://cesonoma.ucanr.edu/files/27187.pdf (Accessed in 1/5/2019)

Walaa, E.-S., El-Kalyoubi, M. H., Abd El-Razik, M. M., \& Abou-Zaid, F. O. F. (2013). Implementation of Hazard Analysis Critical Control Points System (HACCP) During Extraction of Olive Oil by Hydraulic Press. Current Science International.

Wallace, C. A., Sperber, W. H., \& Mortimore, S. E. (2018). Food safety for the 21st century: Managing HACCP and food safety throughout the global supply chain. John Wiley \& Sons.

Zaied, Y. Ben, \& Zouabi, O. (2016). Impacts of climate change on Tunisian olive oil output. Climatic Change, 139(3-4), 535-549. https://doi.org/10.1007/s10584-016-1801-3 